\title{
UPAYA MEWUJUDKAN KOTA LAYAK ANAK DI SURAKARTA DAN MAKASSAR
}

\section{WORTH THE EFFORT TO ACHIEVE THE CITY OF CHILDREN IN SURAKARTA MAKASSAR}

\author{
Moh Ilham A Hamudy \\ Badan Penelitian dan Pengembangan (BPP) Kementrian Dalam Negeri \\ Jl. Kramat Raya No. 132 - Senen, Jakarta \\ No. Telp./Faks : +62 213140454 HP: +62 82111393927 \\ Email : ilhamhamudy80@gmail.com \\ Dikirim: 12 Februari 2015 Direvisi: 24 April 2015 Disetujui: 20 Mei 2015
}

\begin{abstract}
Abstrak
Penelitian ini adalah tentang kota layak anak (KLA). Penelitian ini dilatarbelakangi oleh kurangnya perhatian pemerintah daerah dalam melindungi anak dan keluarnya UU No 35 Tahun 2014 tentang Perlindungan Anak yang mengamanatkan kewajiban pemerintah daerah dalam mengurus anak. Penelitian ini berusaha menggambarkan pelbagai upaya yang dilakukan pemerintah Kota Surakarta dan Makassar dalam mewujudkan KLA, berikut faktor pendukung dan penghambat yang melingkupi perwujudan KLA tersebut. Dengan menggunakan metode deskriptif dan memadunya dengan pendekatan kualitatif, penelitian ini menemukan beberapa poin penting tentang upaya pemerintah daerah dalam mewujudkan KLA. Di Surakarta, misalnya, sudah ada beberapa puskesmas ramah anak. Puskemas itu dilengkapi dengan ruang tunggu khusus anak lengkap dengan alat bermainnya. Selain itu, layanan-layanan untuk anak seperti taman gizi, pojok ASI, dokter spesialis anak, layanan konseling anak dan tempat pelayanan korban kekerasan terhadap anak juga terus dilengkapi, dan masih banyak program lainnya. Tidak heran kalau penilaian Kementerian PPPA memberikan skor 713 dari total nilai yang terdapat dalam 31 indikator KLA yang sudah dipenuhi Kota Surakarta. Sedangkan, Kota Makassar belum banyak program yang dikerjakan pemerintah daerah. Pasalnya, Makassar relatif baru mencanangkan KLA dan kini masih tengah melakukan pembenahan. Di antara program yang baru dan sedang dilaksanakan Pemerintah Kota Makassar adalah pemberian akta kelahiran secara gratis, membangun rumah susun di kawasan kumuh, dan menjadikan dua kelurahan sebagai proyek percontohan KLA. Adapun faktor yang memengaruhi perwujudan KLA itu adalah komitmen. Tidak hanya komitmen kepala daerah, tetapi juga semua pihak terkait. Sebagai sebuah isu yang melibatkan pelbagai pihak, KLA juga membutuhkan kapasitas kelembagaan. Tidak hanya kapasitas Badan Pemberdayaan Perempuan dan Perlindungan Anak sebagai leading sector KLA, tetapi semua satuan kerja perangkat daerah terkait lainnya. Selain itu, program KLA tidak bisa dilakukan dalam waktu singkat, dan memerlukan biaya yang tidak sedikit.
\end{abstract}

Kata kunci: kota layak anak, komitmen, kapasitas kelembagaan.

\begin{abstract}
This study is about child-friendly city (KLA). This research is motivated by the lack of attention of the local government in protecting children and the issuance of Law No. 35 of 2014 on Protection of Children, which mandates local government obligations in the care of the child. This study sought to describe the various efforts made by the government of Surakarta and Makassar in realizing the KLA, the following supporting factors and obstacles surrounding the KLA embodiment. By using descriptive method and combine it with a qualitative approach, this study found some important points about the efforts of local governments in realizing the KLA. In Surakarta, for example, there have been several child-friendly community health centers (puskesmas). The Puskesmas is equipped with a private lounge complete with a children's playground. In addition, services for children such as nutrition garden, corner of breast milk, pediatrician, child counseling services and a child abuse victim services also continue to be equipped, and many other programs. No wonder the Ministry of Women Empowerment and Child Protection Republic of Indonesia assessment scoring 713 from a total value of 31 indicators contained in the KLA who had filled the city of Surakarta. Meanwhile, Makassar City has not done a lot of local government programs, because the relatively new Makassar proclaimed KLA and is still central to reform. Among the new programs are being implemented and the Government of Makassar is giving birth certificate free of charge, to build flats in slums, and make the two villages as a pilot project KLA. The factors that affect the embodiment of the KLA it is a commitment. Not only the commitment of the head region, but also all relevant parties. As a cross cutting issue, the KLA also requires institutional capacity. Not only is the capacity of Women Empowerment and Child Protection Agency as a leading sector in the KLA, but also all work units other related areas. The success of the
\end{abstract}


KLA in a city / county is also very dependent on the commitment of all parties concerned built. In addition, the program can not be done KLA in a short time, and require no small cost.

Keywords: child-friendly city, commitment, institutional capacity.

\section{PENDAHULUAN}

Penelitian ini adalah tentang kota layak anak (KLA). KLA atau yang dalam bahasa Inggris diistilahkan dengan child-friendly city (CFC) awalnya diinisiasi oleh UNESCO melalui program yang dinamakan Growing Up City (Lynch, 1977). Kegiatan ini sendiri diujicobakan di empat negara terpilih, yaitu Argentina, Australia, Mexico dan Polandia. Tujuannya adalah mengetahui bagaimana sekelompok anak-anak usia belasan tahun menggunakan dan menilai lingkungan keruangan (spatial environment) sekitarnya. Selanjutnya, konsep child-friendly city (KLA) diperkenalkan oleh UNICEF dengan tujuan menciptakan suatu kondisi yang mengaspirasi hak-hak anak melalui tujuan, kebijakan, program-program dan struktur pemerintahan lokal (Child Friendly Cities, 2011).

Sementara, yang dimaksud dengan KLA di sini adalah kabupaten/kota yang memunyai sistem pembangunan berbasis hak anak melalui pengintegrasian komitmen dan sumber daya pemerintah, masyarakat dan dunia usaha yang terencana secara menyeluruh dan berkelanjutan dalam kebijakan, program, dan kegiatan untuk menjamin terpenuhinya hak anak (bdk dengan konsep dan tujuan KLA yang dikemukakan Riggio 2002; Gleeson, 2005 dalam Wilks 2010:28; dan Valentine, 1996 dalam Woolcock dan Steele, 2008).

Dalam konteks itu, penelitian ini berusaha menggambarkan pelbagai upaya yang dilakukan pemerintah daerah dalam mewujudkan KLA itu. Selain itu, dalam upaya mewujudkan KLA, penelitian mengungkapkan beberapa faktor pendukung dan penghambat terwujudnya KLA.

Lokus penelitian ini berfokus pada Pemerintah Kota Makassar dan Kota Surakarta. Surakarta dipilih karena di kota itu KLA sudah diwujudkan sejak 2006. Surakarta juga merupakan proyek percontohan yang digagas pemerintah pusat. Harapannya, Surakarta dapat menjadi model KLA bai daerah lainnya di Indonesia. Sementara itu, Kota Makassar sengaja dipilih karena kota itu relatif baru mencanangkan KLA. Sehingga, pada gilirannya akan bisa dilihat perbandingan mencolok antara kota yang sudah lama mewujudkan KLA dengan kota yang baru mencanangkan KLA.

Selain itu, penelitian ini juga bermanfaat dan memiliki relevansi yang tepat dengan tugas pokok dan fungsi Kementerian Dalam Negeri (Kemendagri). Sebab, sebagai kementerian yang membina dan mengawasi pemerintahan di daerah, Kemendagri memiliki kewenangan mensinergikan dan mengoordinasikan program pemerintah pusat yang dikeluarkan Kementerian/Lembaga sektoral agar sukses dalam pelaksanaannya di daerah. Dalam konteks ini, KLA sebagai salah satu program nasional, patut dikawal oleh Kemendagri. Apalagi, urusan perlindungan anak merupakan urusan wajib yang sudah dibebankan kepada daerah. Kemendagri berkewajiban memastikan bahwa urusan itu memang tengah dikerjakan oleh pemerintah daerah.

Sejauh ini sudah cukup banyak penelitian yang pernah mengulas tentang KLA, utamanya penelitian-penelitian yang dilakukan oleh para sarjana barat. Karsten dan van Vliet (2006), misalnya, dalam penelitiannya mengemukakan, upaya penciptaan lingkungan perkotaan ramah anak yang tergambar dari peran jalan sebagai wahana bermain dan pendukung tumbuh kembang anak. Sementara, Tranter dan Pawson (2001), dalam tulisannya bertajuk "Children in the City" yang dimuat dalam Jurnal Youth and Environments lebih banyak menguraikan perihal kemampuan akses anak terhadap lingkungan sekitarnya dalam hal pencapaian kota berkelanjutan dan kota ramah anak di Kota Christchurch, Selandia Baru.

Adapun para sarjana lainnya lebih menekankan penelitian pada aspek lain seperti penekanan arti penting bentuk kota (urban form), dan struktur sosial, serta partisipasi anak di perkotaan (Bridgman, 2004:338). Atau, mengulas tentang peranan dan penggunaan ruang terbuka sebagai arena bermain anak-anak, seperti diungkap Veitch dkk (2007) dalam artikelnya Children's Perception of the Use of Public Open Spaces for Active Free-play

Kalau merujuk pengalaman negara-negara berpenghasilan tinggi seperti Swedia dan Kanada, program KLA senyatanya lebih fokus kepada kebebasan anak dalam bergerak dan berekreasi (Riggio, 2002) dan pengalaman mengenai dampak pembangunan perkotaan terhadap pertumbuhan kesehatan dan kesejahteraan anak dapat diperoleh (Woolcock et al., 2010) sebagaimana terjadi di Australia.

Tidak jauh berbeda dengan penelitian para sarjana barat yang menelaah KLA dari perspektif pembangunan kota, para sarjana lokal di Indonesia juga menekankan penelitian KLA dari sudut pandang hak anak, partisipasinya dalam pembangunan kota, dan persepsi orang tua. Penelitian yang dibuat Widiyanto dan Rijanta (2012), misalnya, mencoba menggenapi apa yang telah diupayakan Riggio (2002). Mereka berdua menambahkan ketigabelas indikator sebagaimana ditulis Riggio. Widiyanto dan Rijanta menguraikan, setidaknya ada empat konsep lagi yang perlu 
ditambahkan guna menyempurnakan uraian Riggio, yaitu konsep kebijakan, perlindungan, lingkungan, dan perencanaan bagi anak.

Keempat konsep itu senyatanya sudah diakomodasi dalam berbagai produk kebijakan di Indonesia, kecuali konsep perencanaan untuk anak yang belum terakomodasi secara eksplisit dalam kebijakan. Menurutnya, konsep perencanaan bagi anak perlu dikaji lebih lanjut untuk diintegrasikan dalam kebijakan yang ada secara eksklusif atau dioperasionalisasikan sebagai bagian dari konsep kebijakan pemerintah.

Sementara Dewi (2011), dalam penelitiannya memandang KLA dari perspektif hak sipil dan partisipasi anak. Dengan mengambil lokus di Kota Kudus, Dewi mendedahkan betapa persoalan anak di sana masih sangat kompleks. Pemenuhan hak sipil dan partisipasi anak juga masih sangat minimal. Hal itu dia lihat dari beberapa indikator, seperti akta kelahiran anak, keterlibatan anak dalam musyawarah perencanaan pembangunan, dan ketersediaan informasi berbasis anak.

Apa yang dikemukakan Dewi, senafas dengan uraian Subiyakto (2012). Menurutnya, meski Hari Anak Nasional sudah diperingati berulang kali, namun nasib anak Indonesia masih belum juga membaik dan belum terlindungi. Masih banyak kasus kekerasan mendera anak-anak. Pembangunan masih parsial dan segmentatif, belum ramah anak.

Kendati begitu, para sarjana di atas meneliti KLA secara parsial saja, dengan sudut pandang tertentu. Berbeda dengan penelitian yang dilakukan oleh beberapa sarjana di atas, penelitian ini berusaha menelaah KLA dari beberapa sudut pandang secara komprehensif, tidak hanya dari sudut pandang pembangunan kota yang memenuhi kebutuhan anak secara fisik, tetapi juga non-fisik. Untuk meringkas pelbagai sudut pandang itu, peneliti menggunakan indikator yang digunakan Kementerian Pemberdayaan Perempuan dan Perlindungan Anak untuk menggambarkan upaya yang telah dilakukan pemerintah daerah dalam mewujudkan KLA.

Penelitian ini juga dianggap penting dan relevan karena melihat konteks kekinian di Indonesia. Sebagai negara yang menjunjung tinggi hak asasi manusia, pemerintah Republik Indonesia menjamin perlindungan dan pemenuhan hak anak yang diatur dalam beberapa peraturan, seperti UUD 1945, peraturan perundang-undangan yang bersifat nasional maupun internasional, pemerintah juga telah meratifikasi Konvensi Internasional tentang Hak-hak Anak yang diimplementasikan dalam UU No 23 Tahun 2002 tentang Perlindungan Anak.

Apalagi, baru-baru ini, tepatnya pengujung September 2014 lalu (25/9), DPR sudah menyetujui RUU tentang Perubahan UU No 23 Tahun 2002 tentang Perlindungan Anak menjadi UU No 35
Tahun 2014 tentang Perlindungan Anak. Dalam UU itu, diatur pula partisipasi pemerintah daerah (pemda) dalam melindungi anak-anak. Partisipasi yang dimaksud adalah pemda wajib melindungi anak.

Kalau dulu, kewajiban untuk menjamin hakhak anak hanya merujuk kepada pemda, tanpa spesifikasi jelas. Hal itu mengakibatkan pemda sering kali sekadarnya, bahkan abai dalam memberi perlindungan kepada anak-anak di wilayah pemerintahan mereka. Pemda umumnya menganggap perlindungan anak merupakan kewajiban pemerintah pusat. Sekarang pemda diberi tanggung jawab dalam melindungi anak secara spesifik.

UU itu sejatinya menegaskan kembali tugas perlindungan anak yang diemban pemda. Sebab, perlindungan anak adalah urusan wajib yang telah diserahkan pemerintah pusat kepada pemda. Rumusan pembagian tugas itu termaktub dalam UU No 32 Tahun 2004 tentang Pemerintahan Daerah, berikut turunannya, yaitu PP No 41 Tahun 2007 tentang Organisasi Perangkat Daerah dan PP No 38 Tahun 2007 tentang Pembagian Urusan Pemerintahan antara Pemerintah, Pemerintahan Daerah Provinsi, dan Pemerintahan Daerah Kabupaten/Kota. Apalagi, secara kelembagaan pemda sudah memiliki Badan Pemberdayaan Perempuan, Perlindungan Anak, dan Keluarga Berencana (BP3AKB).

Namun, karena daerah cakupan lembaga itu terlalu luas, BP3AKB tidak bisa benar-benar fokus kepada perlindungan anak. Adapun lembaga perlindungan anak yang lain pada tingkat pemda ialah Pusat Pelayanan Terpadu Pemberdayaan Perempuan dan Anak (P2TP2A). Sayangnya, P2TP2A hanya tersebar di sedikit wilayah. Itu pun tidak sepenuhnya aktif menjalankan kewajiban, apalagi benar-benar menjamin hak anak. Padahal, pemerintah melalui Peraturan Menteri Pemberdayaan Perempuan dan Perlindungan Anak (Permen PPPA) No 11 Tahun 2011 sudah menggalakkan terbentuknya Kota Layak Anak (KLA) di seluruh Indonesia.

\section{METODE}

Untuk menjawab pertanyaan yang diajukan dalam penelitian ini, peneliti menggunakan metode deskriptif dan dipadu dengan pendekatan kualitatif. Adapun metode pengumpulan data dilakukan dengan mewawancarai sejumlah informan dan menelusuri pelbagai dokumen yang terkait, baik yang dikeluarkan oleh Badan Pemberdayaan Perempuan dan Perlindungan Anak, instansi terkait lainnya, maupun pemberitaan yang dilansir media massa cetak. Sedangkan, asumsi yang coba dibangun adalah berangkat dari pemahaman bahwa dengan terwujudnya KLA, maka hak-hak anak dapat terlindungi. 


\section{HASIL DAN PEMBAHASAN}

Pada bagian ini diuraikan pelbagai upaya yang dilakukan Pemerintah Kota Surakarta dan Kota Makassar dalam mewujudkan KLA di kotanya masing-masing. Selain itu, akan diuraikan beberapa hal yang dianggap sebagai faktor pendukung maupun penghambat upaya perwujudan KLA tersebut.

\section{Upaya Surakarta Mewujudkan KLA}

Pada 2006, Kota Surakarta merupakan salah satu dari 5 Kabupaten/Kota (yakni Kota Surakarta, Kabupaten Gorontalo, Kota Jambi, Kabupaten Sidoharjo, dan Kabupaten Kutai Kartanegara) yang ditunjuk oleh Menteri Negara Pemberdayaan Perempuan RI sebagai pilot proyek pengembangan model KLA di Indonesia. Berdasarkan SK Menteri Negara Pemberdayaan Perempuan RI No SK49/MEN.PP/IV/2007 Tahun 2007 tentang Penetapan Kabupaten/Kota Pengembangan Model Kota Layak Anak, disebutkan bahwa wilayah kerja pengembangan model KLA sudah berkembang menjadi 15 Kabupaten/Kota, salah satunya yaitu Kota Surakarta. Selanjutnya, Pemerintah Kota Surakarta membentuk Tim Pelaksana Pengembangan KLA berdasarkan SK Walikota No 130.05/08/1/2008 dan kemudian membuat MoU No 463/108 tentang Kesepakatan dalam Pengembangan KLA oleh Tim Pelaksana KLA

Oleh karenanya, menindaklanjuti regulasi yang dikeluarkan pemerintah pusat, Pemerintah Kota Surakarta pun menerbitkan regulasi SK Walikota Surakarta No 462.05/84-A/I/2010 tentang Tim Pelayanan Terpadu bagi Perempuan dan Anak Kota Surakarta (PTPAS); Perda Kota Surakarta No 4 Tahun 2012 tentang Perlindungan Anak; SK Walikota Surakarta No 243/I-G/1/2013 tentang Forum Anak Surakarta di Kota Surakarta periode 2013-2015; dan Peraturan Walikota Surakarta No 3-B Tahun 2013 tentang Pedoman Umum Pengembangan Partisipasi Anak dalam Pembangunan di Kota Surakarta.

Berbekal regulasi yang ada, Surakarta membagi beberapa tahap langkah menuju KLA. Tahap pertama tahun 2006-2007 adalah pengembangan model KLA. Dalam tataran yang paling awal ini, pemerintah kota menyusun grand design yang akan jadi patokan untuk pengembangan selanjutnya. Tahap berikutnya 2008-2015 adalah pengembangan kelurahan hingga kecamatan layak anak. Pada 2015, ditargetkan semua kelurahan dan kecamatan selesai dan Surakarta benar-benar menjadi KLA.

Untuk itu, pemerintah kota menuangkannya dalam visi dan misi menuju KLA. Visi KLA Surakarta adalah terwujudnya Kota Surakarta sebagai KLA untuk anak 2015, melalui strategi Pengarusutamaan Hak Anak (PUHA), yang sehat, tumbuh dan berkembang, cerdas ceria, berakhlak mulia, terlindungi dan aktif berpartisipasi serta cinta tanah air.

Adapun misinya (1) Menyediakan pelayanan kesehatan yang komprehensif, merata, dan berkualitas, pemenuhan gizi seimbang, pencegahan penyakit menular termasuk HIV/AIDS, pengembangan lingkungan dan perilaku hidup bersih dan sehat (2) Menyediakan pelayanan pendidikan yang merata, bermutu dan demokratis bagi semua anak sejak usia dini (3) Membangun sistem pelayanan sosial dasar dan hukum yang responsif terhadap kebutuhan anak agar dapat melindungi anak dari segala bentuk kekerasan; dan (4) Membangun lingkungan yang kondusif untuk menghargai pendapat anak dan memberi kesempatan untuk berpartisipasi sesuai dengan usia dan tahapan perkembangan anak.

Sebagai komitmen mewujudkan KLA itu, sejak 2006 Walikota Surakarta aktif menyuarakan hak-hak anak serta mengakomodasi kepentingan terbaik bagi anak dalam menggerakkan pembangunan di Kota Surakarta. Komitmen tersebut ditegaskan pada acara sosialisasi pengembangan Model KLA 2006 dengan peserta dari berbagai unsur yaitu SKPD se Kota Surakarta, DPRD, Muspida, LSM, organisasi masyarakat, organisasi perempuan, rumah sakit, perguruan tinggi, wartawan, Penegak Hukum, Pihak Swasta lainnya di Kota Surakarta. Apalagi, waktu itu, sosialisasi dihadiri sendiri oleh Ibu Meutia Hatta sebagai Menteri Negara Pemberdayaan Perempuan dan Deputi Perlindungan Anak Kementerian Pemberdayaan Perempuan dan Perlindungan Anak.

Tidak heran kalau pemerintah kota begitu gencar membuat pelbagai program yang pro terhadap kebutuhan anak. Sebagai review, sampai akhir 2014, sudah keseluruhan kelurahan (51 kelurahan) di Surakarta telah dikembangkan menjadi kelurahan layak anak. Artinya, kelurahan yang selain punya kepedulian terhadap tumbuh kembang anak, juga sudah mengikutsertakan anak dalam merumuskan program-program kerjanya.

Agar tidak sekadar menjadi gerakan simbolis, Bapermas P3KB Kota Surakarta, sebagai leading sector KLA dan pelaksana utama urusan perlindungan anak di Surakarta, membuat MoU yang ditandatangani oleh 53 elemen dari muspida, perusahaan swasta dan LSM anak. Semua SKPD (satuan kerja perangkat daerah) terkait sudah punya kewajiban mengeluarkan kebijakan yang ramah anak. Bapermas sebagai leading sector bertugas memonitor. SKPD yang tidak punya program atau kebijakan yang pro anak langsung ditegur.

Wujud kebijakan tiap SKPD yang lebih ramah anak sudah mulai bisa dirasakan hasilnya. Di bidang kesehatan sudah mulai ada beberapa puskesmas ramah anak. Pusekemas ini dilengkapi dengan ruang tunggu khusus anak lengkap dengan alat bermainnya. Selain itu, layanan-layanan untuk anak seperti taman gizi, pojok ASI, dokter spesialis 
anak, layanan konseling anak dan tempat pelayanan korban kekerasan terhadap anak juga terus dilengkapi. Tidak heran kalau penilaian Kementrian PPPA memberikan skor 713 dari total nilai yang terdapat dalam 31 inkator KLA yang sudah dipenuhi Kota Surakarta.

Jika dirinci, ada beberapa program yang digalakkan pemerintah kota. Pertama, bidang pendidikan, ada pencanangan Gerakan Wajib Jam Belajar (GWJB). Setiap Ahad s.d Jumat aktif, antara pukul 18.30-20.30 anak-anak diarahkan untuk belajar. Kelurahan Jebres menjadi percontohan pelaksanaa GWJB ini. Secara mandiri masyarakat membentuk semacam satgas yang mengawasi pelaksanaan GWJB. Mereka akan berkeliling kampung sambil melakukan sosialisasi, mengarahkan anak-anak yang masih berada di luar rumah untuk belajar dan menyarankan para orang tua untuk mematikan TV agar tidak menganggu konsentrasi anak. Selain GWJB masih ada sekolah plus, yakni sekolah yang membebaskan seluruh biaya pendidikan untuk anak-anak dari keluarga miskin. Hingga tahun ini sudah ada 16 SD, 5 SLTP dan 2 SMK yang menjadi sekolah plus di Surakarta.

Kedua, di bidang transportasi, Dinas Perhubungan membangun zona selamat sekolah, car free day untuk ruang ekspresi anak, Batik Solo Trans sebagai transportasi ramah anak serta program pembagian helm untuk anak. Ketiga, di bidang kependudukan, Dinas Kependudukan dan Catatan Sipil meluncurkan kartu insentif anak (KIA). Kartu yang diluncurkan tepat pada peringatan Hari Anak Nasional 26 Juli 2010 merupakan kartu diskon untuk belanja di toko buku, sarana olahraga di perhotelan, tempat hiburan anak, rumah sakit, supermarket, bus sekolah dan lain sebagainya. KIA juga bukan sekadar kartu diskon, melainkan berfungsi sebagai kartu identitas anak. Kartu insentif ini sekaligus untuk mendorong para orangtua agar mau membuatkan akta kelahiran bagi anak mereka.

Ada 43 perusahaan yang mendukung KIA, di antaranya PT Askes, Budi Sehat, Gramedia, Togamas, Sekawan, Elti Gramedia, PDAM, Hotel Sunan, Hotel Sahid Jaya, Kusuma Sahid Prince Hotel, THR Sriwedari dan Taman Satwa Taru Jurug. KIA ini juga menjadi sarana untuk mendorong pemberian akta kelahiran untuk setiap anak di Surakarta.

Keempat, pemerintah kota membangun beberapa taman cerdas, di antaranya yang sudah terealisasi adalah di Kelurahan Sumber, Kadipiro, Gandekan, Joyontakan, Mojosongo dan Pajang. Taman ini menyediakan sarana bermain dan berkreasi yang dilengkapi perpustakaan, multimedia, komputer dan akses internet yang semuanya bisa digunakan secara gratis oleh anakanak. Pengelolaan taman cerdas diserahkan kepada masing-masing kelurahan agar lebih maksimal dan sesuai dengan kebutuhan warga setempat.

Bahkan, pada 2013 lalu, Pemerintah Kota Surakarta mengalokasikan anggaran senilai Rp 2,5 miliar guna membangun taman cerdas di Semanggi, Pasar Kliwon. Taman cerdas tersebut dibangun di bekas lahan Permakaman Mipitan, Semanggi, sisi timur. Selain di Semanggi, pembangunan taman cerdas juga dilakukan di Jebres. Sedangkan, untuk pos anggarannya berada di kelurahan masing-masing.

Sejauh ini di Kota Surakarta memang baru terdapat tujuh taman cerdas. Jumlah tersebut direncanakan terus meningkat guna mendukung Surakarta menjadi KLA. Hanya, pembangunan terkendala minimalnya lahan. Sebagai contoh, di wilayah Pasar Kliwon belum satu pun taman cerdas dibangun. Padahal, keinginan masyarakat untuk memiliki taman cerdas cukup tinggi. Hal ini terbukti dari usulan masyarakat terkait pembangunan tersebut dalam setiap musrenbang. Pembangunan taman cerdas tentu memerlukan RTH. Masalahnya, Luas RTH publik di Kota Surakarta baru mencapai 529 ha atau sekira 12,02 persen dari luas wilayah 4.404 ha. Luas RTH sebelumnya bahkan hanya 11,9 persen. Tetapi, setelah ada tambahan dari bantaran sungai, RTH bisa menjadi 21,02 persen.

Kelima, menggagas pendirian radio anak berbasis komunitas. Radio tersebut dikonsep dari, oleh, untuk dan tentang anak. Yang menjadi leading sector adalah Dinas Perhubungan Komunikasi dan Informatika. Dikatakan, keberadaan radio komunitas anak penting untuk menguatkan posisi Surakarta sebagai KLA. Pemerintah kota menjamin anak bakal diberi porsi maksimal dalam radio tersebut. Jadi, mulai bahasan, penyiar dan pendengar radio ditujukan bagi anak. Pengecualian hanya di manajemen.

Kendati begitu, radio tersebut tidak serupa radio pada umumnya. Lantaran berbentuk komunitas, wilayah jangkau radio dibatasi maksimal 2,5 kilometer. Hal itu sesuai dengan PP No 51 Tahun 2005 dan Keputusan Menteri Kominfo No 17 Tahun 2004. Meski demikian, terbatasnya jangkauan radio komunitas anak sejatinya tidaklah menjadi persoalan.

Keenam, membentuk forum anak. Forum anak adalah forum yang dikelola oleh anak dan dibina oleh pemerintah yang digunakan sebagai wadah partisipasi anak di mana anggotanya adalah anak secara individu dan/atau dari perwakilan kelompok anak, sebagai media untuk mendengar dan memenuhi aspirasi suara, pendapat, keinginan, dan kebutuhan anak dalam proses pembangunan. Fungsinya adalah sebagai media pantauan pelaksanaan pemenuhan hak anak, sebagai media sosialisasi program kegiatan terkait dengan hak anak dilingkungan teman sebaya, sebagai media menyuarakan aspirasi anak, mendorong 
keterlibatan anak dalam proses pengambilan keputusan, mendorong anak-anak aktif mengembangkan potensinya.

Terbentuknya forum anak di Kota Surakarta pada 2014 dilakukan untuk menggali aspirasi anak dalam berkreasi dan mencipta. Saat ini di Kota Surakarta sudah terbentuk sebanyak 42 Forum anak yang terbentuk di masing-masing tiap-tiap kelurahan terdapat lebih dari satu forum, sehingga semua berjumlah 51 forum anak.

Kelima puluh satu forum anak tersebut memberi nama forumnya masing-masing yang memiliki keunikan dan kreativitas anak, sebagai contoh di Kelurahan Jebres menamakan Panbers berasal dari kata Forum Anak Jebres, kemudian Tunas Pucang berasal dari Kelurahan Pucang Sawit. Kalau dilihat dari nama-nama yang dibentuk, pihak kelurahan tidak melibatkan diri secara langsung selain tidak memiliki waktu juga untuk memberikan anak kebebasan dalam membentuk forum tersebut.

Ketujuh, sejak tahun lalu, Pemerintah Kota Surakarta telah menyiapkan anggaran lebih dari Rp 1,2 miliar untuk membangun puluhan ruang laktasi atau pojok ASI (Air Susu Ibu) sebagai ruang khusus menyusui di berbagai area publik demi mengejar gelar KLA pada 2015 mendatang. Setiap kantor kelurahan, kecamatan, pasar, serta kantor pelayanan publik lainnya akan dilengkapi dengan ruang menyusui.

Kedelapan, yang tidak kalah pentingnya juga, pemerintah kota telah membuat dokumen Integrasi Rencana Tindak Lanjut Sistem Perlindungan Anak dalam Pembangunan di Kota Surakarta. Dalam dokumen diuraikan berbagai permasalahan yang masih dihadapi terkait pelaksanaan Sistem Perlindungan Anak berbasis System Building Approach (SBA) di Kota Surakarta. Dari hasil pemetaan diketahui bahwa tiap sistem seperti sistem hukum dan kebijakan, sistem peradilan, sistem kesejahteraan sosial, sistem data dan informasi perlindungan anak, dan sistem perubahan perilaku sosial memiliki potensi serta masalah yang mengiringinya.

Potensi sistem hukum dan peradilan adalah aparat penegak hukum yang telah mengetahui berbagai aturan yang terkait Perlindungan Anak seperti salah satunya Perda No 10 Tahun 2010 tentang Penyelenggaraan Adminsitrasi Kependudukan. Selain itu, sudah terdapat kerangka hukum yang teratur dan saksi dari lembaga pelaksana, pendanaan mekanisme pemantauan, koordinasi, dan sanksi. Tetapi, pada praktiknya, masih terdapat masalah, karena kurangnya koordinasi antar-SKPD terkait, sehingga memunculkan ego sektoral yang berarti masih menggunakan pendekatan berbasis isu bukannya SBA.

Sistem peradilan ini memiliki potensi dengan adanya dukungan kelembagaan Pelayanan
Terpadu bagi Perempuan dan Anak Kota Surakarta (PTPAS) yang berbentuk konsorsium, yaitu gabungan dari beberapa institusi/lembaga/organisasi yang memunyai kepedulian terhadap perempuan dan anak, serta melakukan pelayanan terpadu bagi perempuan dan anak sesuai dengan tugas pokok dan fungsi masingmasing, dan dikoordinasikan oleh BAPERMAS PP $\mathrm{PA}$ dan KB.

Selain itu, di Kota Surakarta juga telah memiliki kebijakan terkait kesejahteraan anak dan keluarga, yaitu:

1) Perda No 3 Tahun 2006 tentang Penghapusan Eksploitasi Seksual Komersial.

2) MoU tentang Pelayanan Terpadu bagi Perempuan dan Anak Kota Surakarta (PTPAS).

3) SK Walikota Surakarta No. 462.05/84A/1/2010 tentang Pelayanan Terpadu bagi Perempuan dan Anak Kota Surakarta.

Namun, masalah yang masih menghadang sistem kesejahteraan sosial di Surakarta adalah pelayanan berkesinambungan (continuous care) terkait perlindungan anak yang belum ada seperti rumah rehabilitasi/rumah singgah. Sistem data dan informasi perlindungan mengalami berbagai masalah, seperti: adanya kesenjangan antara kebijakan tingkat nasional dan tingkat daerah mengenai mekanisme pengumpulan, pengolahan, dan pemanfaatan data dan informasi terkait perlindungan anak.

\section{Makassar Menuju KLA}

Makassar telah mencanangkan KLA pada 22 September 2014 lalu, langsung oleh Walikota Makassar. Pencanangan Makassar sebagai KLA, tentu merupakan terobosan berani yang dilaksanakan Pemerintah Kota Makassar melalui Tim Penggerak PKK Kota Makassar dan Badan Pemberdayaan Perempuan dan Perlindungan Anak (BPPPA) Kota Makassar. Tujuan pencanangan itu adalah untuk membangun inisiatif pemerintah kota agar mengarah pada kebijakan, program, strategi dan kegiatan pembangunan yang mengutamakan hak anak.

Pencanangan tersebut menjadi sebuah langkah awal bagi Pemerintah Kota Makassar untuk berusaha memenuhi lima hal pokok bagi masyarakat, khususnya anak-anak. Yakni, hak sipil atau kebebaaan, lingkungan keluarga dan alternatif, persiapan hak dasar dan kesejahteraan, pendidikan, serta perlindungan khusus.

Melalui pencanangan itu diharapkan pemerintah dalam setiap kebijakannya selalu memerhatikan hak kebutuhan anak, mulai dari pendidikan dan kebebasan dalam bermain. Menyiapkan generasi muda yang berkualitas sebagai penerus dan pewaris bangsa berarti membangun dan mensejahterahkan kehidupan anak sedini mungkin. Sebagai program awal pemerintah kota membentuk Gugus Tugas KLA melalui 
Keputusan Walikota Makassar No 463.05/1288/Kep/XI/2013.

Namun, sayangnya, pencanangan itu terkesan terburu-buru. Padahal, ada 31 indikator yang mesti dipenuhi untuk bisa mengatakan sebuah kabupaten/kota tepat disebut KLA. Minimal, menurut pihak Badan Pemberdayaan Perempuan Provinsi Sulawesi Selatan, pencanangan KLA didahului dengan terpenuhinya sekira 70 persen dari indikator KLA.

Kendati begitu, Pemerintah Kota Makassar tetap mencanangkan KLA dengan segala kekurangan yang ada. Menurut Walikota Makassar, selama ini masih banyak anak yang belum terpenuhi hak-haknya, salah satunya adalah akses ruang bermain (Fajar, 23/9/2014).

Meski di beberapa tempat, menyediakan wahana permainan, namun dengan harga yang mahal, sehingga tidak semua anak dapat merasakan masa bermain yang layak di usianya. Untuk itu, pemerintah kota berjanji mengeluarkan kebijakan dalam penyedian taman bermain yang dapat digunakan sebagai ruang bermain anak yang nyaman.

Karena penyediaan taman bermain itu mensyaratkan ketersediaan RTH, kini pemerintah kota mulai serius melakukan pembenahaan aspek lingkungan, khususnya penambahan persentase RTH yang masih jauh dari target 30 persen RTH dari luas wilayah Kota Makassar. Sebagai informasi, Badan Lingkungan Hidup Kota Makassar mencatat, RTH di Makassar masih kurang dan tidak seimbang antara laju pembangunan. Dari sekira 175 kilometer persegi luas Kota Makassar, RTH hanya tersedia sebanyak 8 persen.

\section{Makassar Membangun KLA dari Kawasan Kumuh}

Dijanjikan oleh walikota, dalam waktu dekat ini akan membangun taman di 14 kecamatan di Kota Makassar, yang nantinya menjadi area bermain bagi anak-anak. Selain itu, pemerintah kota juga akan merevitalisasi kota yang padat dan kumuh. Sebab, di sana tempat hidup banyak anakanak miskin dan kumuh. Banyak anak yang tidak bersekolah di sana, mereka banyak yang mengemis di jalan yang punya risiko besar dalam hal keselamatan.

Sebagai gambaran, hampir sepertiga penduduk Makassar tinggal di daerah kumuh. Berdasarkan data Badan Perencanaan Pembangunan Daerah (Bappeda) Kota Makassar, saat ini sebanyak 432.115 jiwa atau 131.299 kepala keluarga (kk) dari total penduduk Kota Makassar sekira 1,4 juta orang hidup masih hidup dan menetap dalam kawasan permukiman kumuh Makassar.

Salah satu program utama pemerintah kota adalah mengurangi pemukiman kumuh dengan membangun rumah susun (Rusun). Sebagai contoh, kawasan yang telah dibangun adalah lima twin block Rusun Mariso dan empat twin block Rusun Panambungan, Kecamatan Mariso. Pada 2014 ini pemerintah kota memprioritaskan penataan permukiman kumuh di daerah padat penduduk sebelah barat kota. Pemerintah Kota Makassar menata kawasan kumuh Kelurahan Buloa, Kecamatan Tallo. Pemerintah Kota Makassar menyiapkan lokasi dan pematangan lahan. Sedangkan bangunan direncanakan dari pemerintah pusat pada APBN 2015.

Kawasan kumuh Tallo ditata bersama Dirjen PU. Ini adalah langkah awal, pemerintah kota akan fokus pada satu kawasan, yaitu kawasan Tallo, yang bisa dibilang sebagai kawasan kumuh dan miskin yang paling luas di Makassar. Fokus pada satu kawasan, akan lebih efektif, sebab hingga saat ini kawasan kumuh di Makassar tidak pernah berkurang dari segi kuantitas. Program penataan kawasan kumuh sebelumnya pernah dilakukan Pemerintah Kota Makassar, tetapi hasilnya tidak begitu baik. Program penataan permukiman kumuh perkotaan ini, dilakukan melalui program Neighborhood Upgrading and Shelter Sector Project (NUSSP) yang sudah mulai dilakukan sejak 2014 hingga 2017.

Berdasarkan data Bappeda Makassar, permukiman kumuh yang tersebar di seluruh kecamatan menempati area seluas 47,62 km persegi. Jumlah itu sekira seperempat dari dari total luas Kota Makassar yang mencapai 175,8 km persegi. Dari 14 kecamatan di Makassar, warga yang tinggal dalam kawasan permukiman miskin paling banyak di Tamalate sebanyak 15.893 kk menempati area sekira 2,5 km persegi.

Di antara tempat miskin dan kumuh itu, pemerintah kota menaruh perhatian khusus kepada dua kelurahan di Kelurahan Manggala Kecamatan Manggala dan Kelurahan Baraya di Kecamatan Bontoala untuk dijadikan proyek percontohan kelurahan layak anak. Sebagai gambaran, di Kelurahan Manggala, misalnya, wilayah kelurahan itu didominasi oleh sampah. Maklum, di sana terdapat tempat pembuangan akhir sampah (TPAS). Sehingga, tidak heran kalau komunitas pemulung cukup banyak di sana. Di antara pemulung itu (bahasa Makassar: payabo) adalah anak-anak. Mereka berasal dari latar belakang etnis yang berbeda, yaitu: etnis Bugis, Kajang dan Makassar yang berasal dari Kabupaten Sinjai, Jeneponto, Takalar, Maros, Bantaeng, Bulukumba, Gowa dan Kota Makassar.

Beberapa lembaga independen dan swadaya yang bekerja sama dengan pemerintah Kota Makassar melakukan pendampingan terhadap anakanak di sana. Aktivitas pendampingan yang dilakukan oleh Yayasan Pabbatta Ummi (Yapta-U) dan lembaga lain di TPAS Antang, adalah salah satu contohnya. Dalam melakukan aktivitasnya, 
Yapta-U melakukan kegiatan secara independen dan swadaya bekerja sama beberapa lembagalembaga, seperti UNICEF, Plan International, ILO, Kementerian Sosial RI dan Dinas Sosial Provinsi dan Kota Makassar.

Dengan pelbagai pendampingan itu, terjadi perubahan sosial dalam komunitas payabo di sana. Perubahan sosial dapat dilihat pada bidang pendidikan, kesehatan, ekonomi, hubungan antarindividu dan organisasi kelompok. Pada bidang pendidikan, saat ini, semua anak pemulung usia sekolah telah menikmati pendidikan dasar (SD), untuk pendidikan menengah, sebagian besar telah menyelesaikan jenjang pendidikan SMP dan SMA, bahkan sudah ada yang menyelesaikan pendidikan tinggi pada tingkat strata-1.

Peningkatan pendidikan merupakan manifestasi dari terjadinya perubahan pola pikir dan perilaku anggota dan keluarga komunitas pemulung. Selain pada pendidikan formal, keberadaan Sanggar Kegiatan Warga (SKW) menjadi ruang pendidikan informal bagi anak-anak dan ibu rumah tangga komunitas pemulung. Dengan demikian, terjadi peningkatan kapasitas para ibu rumah tangga dan anak-anak. Hal ini menyebabkan terjadinya perubahan dan pola kerja pada komunitas pemulung.

Peningkatan kualitas pendidikan juga berimplikasi positif pada peningkatan kualitas kesehatan mereka. Saat ini, hampir semua rumah komunitas pemulung telah bersifat semi permanen. Pada rumah mereka, telah terdapat jamban keluarga. Sumber air bersih dari PDAM juga telah mengalir. Karena itu, pola perilaku sosial dalam bidang kesehatan masyarakat juga mengalami perubahan positif.

Hal yang menggembirakan juga, selama dua tahun terakhir, UNICEF dan BaKTI, bekerja sama dengan Pemerintah Kota Makassar melakukan pendampingan intensif kepada anak-anak di sana. Salah satunya adalah melalui Pelatihan Anak sebagai Pusat Perubahan untuk Pencegahan Kekerasan terhadap Anak di Kelurahan Baraya dan Kelurahan Manggala Kota Makassar. Pelatihan itu diikuti oleh perwakilan siswa dan anak yang masih duduk di jenjang SMP atau SMA di Baraya dan Manggala.

Mereka adalah anak dari orang tua yang telah mengikuti Pelatihan Menjadi Orang Tua Dambaan Anak (Parenting Skills Training) yang telah dilaksanakan sebelumnya. Tujuan kegiatan itu adalah memperkuat kapasitas anak dalam memahami hak anak, perkembangan/komunikasi anak, perlindungan anak, pencegahan bullying, dan menghindari kekerasan. Diharapkan, dengan pelatihan seperti itu pemahaman dan keterampilan anak dalam menggunakan berbagai jalur untuk membuat sebuah perubahan anak yang lebih baik tanpa kekerasan bisa didapatkan.
Membangun kota dari kawasan kumuh ini pada hakikatnya sejalan dengan visi Kota Makassar yang sedang diperjuangkan. Visi yang didengungkan Pemerintah Kota Makassar adalah “Makassar Kota Dunia” pada 2020 (Bisnis Indonesia, 20/05/2013). Selama ini geliat pembangunan kota dengan citra global coba ditampilkan dengan penataan Anjungan Losari, revitalisasi Karebosi dan pembuatan masjid terapung pertama di Indonesia. Para penyokong visi ini berkeyakinan, dengan pertumbuhan ekonomi Kota Makassar yang mencapai 9,5 persen, semua visi tersebut dapat terwujud dengan berdasar pada beberapa kriteria World City seperti ciri ekonomi, ciri politik, ciri budaya, dan ramah terhadap anak.

Itulah sebabnya, bisa dikatakan juga, visi world city yang digaungkan Kota Makassar sejatinya senafas dengan KLA yang sedang dibangun. Langkah-langkah Makassar menciptakan sebuah kota dunia terutama layak anak tercipta apabila terdapat keikhlasan dan ketulusan semua pihak terkait dalam mengutamakan kepentingan terbaik anak. Hal itulah yang ditangkap pemerintah kota di Makassar. Meski bukan kota pertama yang menyandang predikat layak anak, Kota Makassar berupaya menuju ke arah itu.

\section{Program KLA Lainnya}

Program KLA lainnya yang patut dibanggakan dari Kota Makassar adalah akta kelahiran gratis. Program ini telah dimulai sejak 2006, di mana pemerintah kota saat itu telah memberikan 10.000 akta kelahiran gratis, yang dilanjutkan pada 2007 dengan jumlah yang sama. Program ini sendiri dirancang dan diperuntukkan hanya bagi anak-anak yang berasal dari keluarga tidak mampu atau keluarga miskin.

Untuk mendapatkan akta kelahiran gratis caranya sangat mudah dan tidak berbelit-belit. Masing-masing kepala keluarga (KK), cukup memperlihatkan kartu miskin atau keterangan tidak mampu dari pemerintah setempat, dan langsung mendaftar di Dinas Kependudukan dan Catatan Sipil untuk didata dan diproses berkasnya. Jika ditotalkan secara keseluruhan, maka jumlah akta kelahiran gratis yang telah diberikan Pemerintah Kota Makassar kepada masyarakat sampai akhir 2013 kemarin adalah sebanyak 32.500. dengan jumlah sebanyak itu pemerintah kota tetap terus mengawasi pelaksanaannya, sehingga dapat tepat sasaran dan efektif dalam pelaksanaannya.

Selain itu, Pemerintah Kota Makassar melalui BPPPA sudah memiliki Tim P2TP2A yang cukup baik dalam penanganan perlindungan anak karena melibatkan berbagai stakeholders. Tim bentukan Pemerintah Kota Makassar juga telah dilengkapi dengan beberapa perangkat, termasuk telah memunyai rumah aman (shelter) yang telah 
dimanfaatkan. Pemerintah Kota Makassar juga memunyai program penanganan pekerja anak, khususnya pemulung, yang terintergrasi dari beberapa SKPD dan stakeholders nonpemerintah.

Tim P2TP2A Kota Makassar melakukan pelayanan bagi perempuan dan anak korban tindak kekerasan dan berupaya memberikan kontribusi terhadap pemberdayaan perempuan dan anak dalam rangka terwujudnya kesetaraan dan keadilan gender serta kesejahteraan. Di antara pelayanan itu berbentuk pemberian layanan informasi, pelayanan, pendampingan psikologis dan advokasi hukum terhadap perempuan dan anak, membangun komitmen dan gerakan bersama untuk mencegah, memberdayakan dan menanggulangi tindak kekerasan dan trafficking terhadap perempuan dan anak serta menjadikan P2TP2A sebagai basis pemberdayaan perempuan dan anak secara preventif, kuratif, rehabilitatif dan promotif.

Kendati begitu, seperti digambarkan sebelumnya, masih banyak indikator yang terangkum dalam 31 indikator KLA yang belum dipenuhi Kota Makassar. Hal itu tercermin dari minimalnya program, kegiatan, dan output yang dihasilkan. Sebagai kota yang baru mencanangkan KLA, memang belum banyak yang bisa dibanggakan dari pencapaian Kota Makassar. Tentu hal ini sangat berbeda dengan apa yang telah berlaku di Kota Surakarta. Kendati begitu, upaya pencanangan KLA tetap patut diapresiasi

\section{Faktor Pendukung Program KLA}

Jika dipetakan, ada beberapa hal yang mendukung keberlangsungan KLA di kedua kota dalam penelitian ini. Pertama, komitmen semua jajaran pemerintahan Kota Surakarta, DPRD, sektor swasta, LSM dan masyarakat. Di Kota Surakarta, sejak zaman Joko Widodo menjadi walikota, komitmen itu sudah ditunjukkan. Sekarang, meski berganti kepemimpinan, Walikota FX Hadi Rudyatmo pun tetap memegang teguh komitmen tersebut.

Kedua, advokasi dan sosialisasi kebijakan KLA kepada pimpinan stakeholders, sehingga terwujud komitmen (SKPD, LSM, organisasi masyarakat, perguruan tinggi, penegak hukum, sektor swasta, tokoh agama, tokoh masyarakat, orang tua, anak-anak) dalam pemenuhan hak-hak anak serta mengakomodasi kepentingan terbaik bagi anak dalam KLA.

Ketiga, Tim Pelaksana Pengembangan KLA di Kota Surakarta (SK Walikota Surakarta No.130.05/08/1/2008 tentang Tim Pelaksana PKLA Kota Surakarta, yang telah diperbarui dengan SK Walikota Surakarta No.130.05/56.4/1/2010. Keempat, penandatangan MoU No.463/108 tentang Kesepakatan dalam Pengembangan KLA oleh Tim Pelaksana PKLA.
Kelima, program KLA Surakarta dituangkan dalam Rencana Aksi Kota Pengembangan Kota Layak Anak (RKA-PKLA) Kota Surakarta 20082015 (SK Walikota No.054/08-E/1/2009), yang penyusunannya didasarkan pada baseline data tentang permasalahan anak, identifikasi kegiatan dan permasalahan anak, serta indikator yang telah ditentukan. Keenam, monitoring dan evaluasi pada setiap kegiatan dan akhir tahun. Sehingga, efektivitas program KLA dapat tercapai dengan baik.

Pada batas dan poin tertentu, hal yang sama terjadi di Kota Makassar. Walikota Danny Pomanto juga menunjukkan komitmen yang kuat. Bahkan, sejak sebelum pencanangan KLA, Danny sudah berkomitmen saat kampanye pemilihan Walikota Makassar tempo hari. Dalam kampanyenya ia selalu berkoar akan membangun Kota Makassar dimulai dari lorong (gang).

Dengan memopulerkan tagline "Anak Lorongna Makassar” dalam kampanye, Danny bercita-cita seluruh anak di Makassar terutama yang berada di gang-gang kecil dan sempit diberi prioritas pembangunan. Tidak hanya pembangunan fisik, tetapi juga non-fisik. Tetapi, sekali lagi, hasilnya memang belum bisa diuji sepenuhnya seperti halnya Kota Surakarta.

Dalam rancangan APBD 2015 BPPPA Kota Makassar juga telah mengalokasikan anggaran sekira Rp 800 juta rupiah untuk menggarap indikator KLA termasuk melayani dua kelurahan di Makassar yang telah dijadikan proyek percontohan KLA. Dalam pada itu, karena KLA adalah isu yang sifatnya cross cutting, anggaran yang terkait dengan indikator KLA juga terdapat di SKPD lain. Yang patut diapresiasi juga, program KLA di Makassar sudah dimasukkan dalam RPJMD Kota Makassar 2015-2020. Hal ini bisa menjamin, berbagai indikator yang ada dalam KLA bisa tercantum dalam RKPD dan dibiayai APBD setiap tahunnya.

\section{Faktor Penghambat Program KLA}

Di samping diuntungkan oleh adanya faktor pendukung, pemerintah kota senyatanya juga menghadapi pelbagai tantangan (khususnya di Kota Makassar) yang pada batas tertentu bisa dikatakan sebagai faktor penghambat. Sementara di Surakarta, faktor penghambat dapat dikatakan sudah dapat diatasi sejak beberapa waktu lalu. Ada beberapa hal yang dapat dikatakan sebagai faktor penghambat.

Pertama, Gugus Tugas KLA. Di Makassar, meski Gugus Tugas KLA sudah dibentuk melalui Keputusan Walikota Makassar No 463.05/1288/Kep/XI/2013 kendala masih sering dan banyak dijumpai. Misalnya, dalam setiap rapat koordinasi, yang hadir dalam rapat itu kerap berganti-ganti orang atau utusan, sehingga sosialisasi selalu dilakukan secara berulang-ulang. 
Bagi SKPD program KLA dianggap kurang “seksi” dan tidak mampu mendongkrak "citra" pejabat di masyarakat. Tampak juga, mind set SKPD masih mengedepankan "egosektoral”, mereka berpikir, urusan anak hanyalah urusan Badan Pemberdayaan Perempuan dan Perlindungan Anak, bukan urusan mereka.

Cara berpikir seperti itu dapat menghambat terwujudnya Makassar sebagai KLA, sebab semua SKPD sebetulnya harus mengintegrasikan kepentingan dan kebutuhan anak dalam program dan kegiatan mereka atau yang disebut dengan pengarusutamaan hak anak.

Kedua, kapasitas kelembagaan pelaksana KLA. Khusus untuk Kota Makassar, kapasitas kelembagaan tidak begitu kuat. Contohnya, sarana prasarana minim, pegawai yang ditempatkan belum semuanya paham tentang pengarusutamaan anak. Kebanyakan di antara pegawai adalah bukan orang yang berkecimpung lama di BPPPA, melainkan dari instansi lain, seperti kelurahan kecamatan, atau pun sekretariat daerah. Hanya segelintir yang memahami KLA. Sayangnya, mereka ditempatkan bukan pada bidang pengarusutamaan anak.

Komitmen Kepala BPPPA Makassar sendiri patut dipertanyakan. Yang bersangkutan jarang sekali berada di kantor, apalagi berkoordinasi dengan SKPD lain dan BPPPA Provinsi Sulawesi Selatan. Padahal, Kepala BPPA adalah orang lama di BPPA (ketika itu masih berupa kantor). Justru Kepala BPPPA periode sebelumnya lebih berkomitmen, tetapi yang bersangkutan dipindahkan ke SKPD lain. Sementara, model birokrasi di BPPA Makassar masih bersifat instruktif, sehingga dibutuhkan komitmen dari pimpinan untuk mau menggerakan bawahanya.

Ringkasnya, soal penempatan pegawai yang kurang memperhatikan prinsip the right man on the right place sehingga banyak pegawai yang ditempatkan tidak sesuai dengan kompetensi yang dimilikinya. Belum lagi kalau organisasi dihadapkan pada persoalan mutasi dan rolling yang sewaktu-waktu bisa dilakukan membuat pelaksana programmenjadi setengah hati. Sebab, pekerjaanpekerjaan yang belum terselesaikan menjadi terbengkalai. Yang menjadi focal point-nya dimutasi.

Ketiga, dengan kondisi itu, berimpak kepada hal yang lain, seperti base line data anak. Data anak ini dikatakan penting karena sebagai eye opener atau pintu pembuka untuk mengetahui problem dan kebutuhan dasar anak. Data tersebut bisa bersifat kuantitatif maupun kualitatif. Problem dan kebutuhan dasar inilah yang akan menjadi basis penyusunan program dan yang akan menentukan yang akan menjadi fokus program serta Rencana Aksi Daerah (RAD) di Kota Makassar. Masalahnya, base line data anak ini tidak ada atau belum dibuat oleh BPPPA Makassar dan SKPD lainnya.
Harusnya masing-masing SKPD melakukan pendataan anak di masing-masing sektor. Kalau pun ada hanya di Dinas Dukcapil, tetapi SKPD yang lain belum. Apalagi, ada perbedaan definisi anak di UU Perlindungan Anak dan UU Ketenagakerjaan, jadi agak susah untuk mendata pekerja anak. Dalam UU Perlindungan Anak, yang dimaksud dengan anak adalah mereka yang berusia 0-18 tahun, tetapi dalam UU Ketenagakerjaan anak itu mulai 0-15 tahun. Sementara, UU Pemilu mendefinisikan anak adalah mereka yang berusia kurang dari 17 tahun. Perbedaan definisi anak inilah yang menyebabkan data dasar anak di masing-masing SKPD harus disesuaikan. Maka, di sinilah pentingnya duduk bersama menyamakan persepsi tentang anak dan problemnya.

Saat ini fokus program dan RAD di Kota Makassar baru sampai tahap penyusunan oleh gugus tugas. Berdasarkan hasil wawancara diketahui bahwa sampai hari ini fokus program belum terumuskan, sebab faktor kehadiran utusan dalam rapat-rapat koordinasi bukan orang yang sama, sehingga untuk merumuskan persoalan anak yang mau diadvokasi sulit terumuskan, karena harus mulai dari memberi pemahaman kepada peserta yang hadir dulu tentang hak anak.

Keempat, keterlibatan anak dalam Musrenbang. Di Kota makassar, setiap Musrenbang di setiap tingkatan, mulai dari kelurahan sampai tingkat kota tidak pernah melibatkan anak. Meski forum anak di Makassar sudah terbentuk, tetapi mereka belum melakukan kegiatan yang berarti.

Sejauh ini sudah ada forum anak yang beranggotakan 50 anak yang diambil dari pelbagai sekolah setingkat SMP dan SMA di Makassar. Tetapi kegiatannya masih nol, apalagi ikut musrenbang, mereka belum pernah melaksanakannya. Padahal, dari 31 indikator KLA, pembentukan forum anak dan musrenbang anak, penilaiannya sangat tinggi.

\section{KESIMPULAN}

Untuk menciptakan KLA di Indonesia diperlukan kesamaan paradigma mengenai anak. Dibutuhkan kerja sama yang baik di antara berbagai pihak yang betul-betul mau mengedepankan kepentingan terbaik untuk anak. Dari dua lokus yang telah digambarkan dalam penelitian ini, terdapat banyak upaya yang telah dilakukan pemerintah kota, baik Surakarta dan Makassar. Sebagai kota yang telah lebih dulu mencanangkan KLA, program KLA di sana sudah lebih banyak dibandingkan Makassar.

Di Surakarta, misalnya, sudah ada beberapa puskesmas ramah anak. Puskemas itu dilengkapi dengan ruang tunggu khusus anak lengkap dengan alat bermainnya. Selain itu, layanan-layanan untuk anak seperti taman gizi, pojok ASI, dokter spesialis anak, layanan konseling anak dan tempat pelayanan 
korban kekerasan terhadap anak juga terus dilengkapi, dan masih banyak program lainnya. Tidak heran kalau penilaian Kementerian PPPA memberikan skor 713 dari total nilai yang terdapat dalam 31 indikator KLA yang sudah dipenuhi Kota Surakarta.

Sementara itu, Kota Makassar belum banyak program yang dikerjakan pemerintah daerah. Pasalnya, Makassar relatif baru mencanangkan KLA dan kini masih tengah melakukan pembenahan. Di antara program yang baru dan sedang dilaksanakan Pemerintah Kota Makassar adalah pemberian akta kelahiran secara gratis, membangun rumah susun di kawasan kumuh, dan menjadikan dua kelurahan sebagai proyek percontohan KLA.

Upaya mewujudkan hal itu harus diakui tidaklah mudah dan cepat. Dibutuhkan tahapan yang panjang, uang yang tidak sedikit, dan waktu yang tidak sebentar. Begitu juga dengan faktorfaktor yang memengaruhinya. Komitmen semua pihak terkait adalah faktor utama. Komitmen semua pihak itu tidak hanya pada level pemerintah pusat tetapi juga di level pemerintah daerah. Kapasitas kelembagaan, yang ditunjukkan dengan ketersediaan dana, sumber daya manusia dalam menguasai substansi KLA dan merancang pelbagai program yang memerlukan kerja sama dengan banyak pihak, juga merupakan faktor determinan keberhasilan maupun kegagalan KLA.

Tidak kalah pentingnya, dukungan pemerintah pusat merupakan sebuah keniscayaan. Kemendagri, misalnya, seyogyanya dapat memberikan kemudahan berupa fasilitasi dan dorongan kepada semua kepala daerah kabupaten/kota melalui melalui penerbitan Surat Edaran Menteri Dalam Negeri tentangnya pentingnya percepatan KLA, khususnya dalam hal kemudahan pengalokasian anggaran indikator KLA dalam dokumen perencanaan dan penganggaran daerah.

Selain itu, evaluasi rancangan perda (raperda) tentang tata ruang daerah kabupaten/kota oleh pemerintahan daerah provinsi dan evaluasi raperda tentang tata ruang daerah provinsi oleh pemerintah pusat melalui Kemendagri, agar secara berjenjang menekankan pada ketersediaan RTH dan ruang bermain anak serta secara selektif melarang alih fungsi lahan hijau.

Kemendagri selaku koordinator pembinaan dan pengawasan penyelenggaraan pemerintahan daerah kiranya juga perlu mendorong kementerian terkait (Kementerian Dikdasbud dan Kementerian PPPA) untuk menetapkan standar pelayanan minimal (SPM) Pendidikan Dasar dan Menengah yang berpihak kepada anak sesuai masa pertumbuhannya, tidak merampas masa bermain anak untuk alasan kurikulum, serta penetapan NSPK perlindungan anak, termasuk di dalamnya pelaksanaan kebijakan pelayanan publik berbasis anak. 


\section{Daftar Pustaka}

Bridgman, R. 2004. "Criteria for Best Practices in Building Child-Friendly Cities: Involving Young People in Urban Planning and Design”, Canadian Journal of Urban Research 13 (2). 337-346

Child Friendly Cities. 2011. The CFC Initiative. http://www.childfriendlycities.org/en/overview the-cfcinitiative diakses pada 27 Oktober 2014

Dewi, Siti Malaiha. 2011. Transformasi Kudus sebagai Kota Layak Anak: Tinjauan atas Pemenuhan Hak Sipil dan Partisipasi. Muwazah 3 (1) Juli. 398-410

Karsten, L \& van Vliet, W. 2006. "Children in the City: Reclaiming the Street”. Children, Youth and Environments. 16 (1). 151-167

Lynch, K (Editor). 1977. Growing up in Cities: Studies of the Spatial Environment of Adolescence in Cracow, Melbourne, Mexico City, Salta, Toluca dan Warsawa, The MIT Press dan UNESCO, Cambridge

Riggio, E. 2002. "Child friendly cities: good governance in the best interest of the child". Environment and Urbanization 14 (2). 45-58

Subiyakto, Rudi. 2012. Membangun Kota Layak Anak: Suatu Kebijakan Publik di Era Otonomi Daerah. Sosio-Religia 10 (1). Februari. 49-71

Tranter, P., \& Pawson, E. 2001. "Children Access to Local Environments: a case- study of Christchurch, New Zealand”. Local Environment 6 (1). 27-48
Veitch, J., Salmon, J., \& Ball,K. 2007. “Children’s Perception of the Use of Public Open Spaces for Active Free-play”. Children's Geographies 5 (4). 409-422

Wilks, Judith. 2010. "Child-Friendly Cities: a place for active citizenship in geographical and environmental education”. International Research in Geographical and Environmental Education, 19 (1). 25-38

Widiyanto, Dodi dan R. Rijanta. 2012. Lingkungan Kota Layak Anak Berdasarkan Persepsi Orang Tua di Yogyakarta. Bumi Lestari 12 (2) Agustus. 211-216

Woolcock, G \& Steele, Wendy. 2008. Child-Friendly Community Indicators- A Literature Review. Based on a Report Prepared by Urban Research Program for the NSW Commision for Children \& Young People. Griffith University: Nathan

Woolcock, G., Gleeson, B., \& Randolph, B. 2010. "Urban Research and Child-Friendly Cities: a New Australian Outline”. Children's Geographies 8 (2). 177-192

\section{Surat Kabar}

Makassar Canangkan Kota Layak Anak (Fajar, 23/9/2014)

Makassar Targetkan 2020 Sama Dengan Kota Dunia (Bisnis Indonesia, 20/05/2013) 